\title{
Kualitas Audit Didasarkan Pada Isu-Isu Keahlian Dan Profesionalisme Auditor
}

Mohammad Ali Sartono*

*Universitas Islam Syekh-Yusuf Tangerang

\begin{tabular}{l|}
\hline \multicolumn{1}{c|}{ ARTICLE INFO } \\
\hline Keywords: \\
Quality audits, \\
expertise, \\
professionalism auditors
\end{tabular}

email:

ali.sartono@centrin.net.id ABSTRACT

This research will examine the views from stakeholders on the quality of audits based on issues of expertise and professionalism of auditors, audits commercialization and transparency the audit. This study focuses attention on the response from implementation of audits quality regulations according to the company's audits, the audit committee and investors. The focus of this research is an analysis of research by identifying four major drivers of audit quality, namely: culture in an audit firm; skills and personal qualities of audit partners and staff; the effectiveness of the audit process; the reliability and usefulness of audit reporting. In this study also identifies a number of factors that affect the quality of audit beyond the control of the auditor, namely: the approach taken by management; the contribution made by the audit committee; role of shareholders and commentators; role as a driver of audit quality litigation; regulatory approaches; the pressure caused by the acceleration reports. The results showed that the regulatory bodies and professionals involved in the management and improvement of audit quality to make efforts to improve the tarnished image, increase its legitimacy and reputation as well as the dominance of responses raised concerns about potential damage to the profession.

Penelitian ini akan mengkaji pandangan dari para pemangku kepentingan (stakeholder) terhadap kualitas audit yang didasarkan pada isu-isu mengenai keahlian dan profesionalisme auditor, komersialisasi audit dan transparansi pelaksanaan audit. Penelitian ini memfokuskan perhatian pada tanggapan dari pelaksanaan peraturan kualitas audit menurut perusahaan audit, komite audit dan investor. penelitian ini merupakan fokus dari analisis penelitian ini dengan mengidentifikasi empat penggerak utama kualitas audit, yaitu: budaya dalam sebuah perusahaan audit; keterampilan dan kualitas pribadi dari mitra audit dan staf; efektivitas proses audit; keandalan dan kegunaan pelaporan audit. dalam penelitian ini juga mengidentifikasi sejumlah faktor yang memengaruhi kualitas audit di luar kendali auditor, yaitu: pendekatan yang diambil oleh manajemen; kontribusi yang dibuat oleh komite audit; peran pemegang saham dan komentator; peran ligitasi sebagai penggerak kualitas audit; pendekatan regulator; tekanan yang disebabkan oleh percepatan laporan. hasil penelitian menun-

Manajerial

Volume 9 Nomor 2

November 2015 -April 2016

ISSN 2477-1376

hh. $79-88$ jukkan bahwa badan pengawas dan profesional terlibat dalam manajemen dan peningkatan kualitas audit untuk melakukan upaya memperbaiki citra yang tercoreng, meningkatkan legitimasi dan reputasi serta dominasi tanggapan yang menimbulkan kekhawatiran terhadap potensi kerusakan pada profesi. 


\section{Pendahuluan}

Di dalam profesi akuntansi, adanya krisis keuangan global dan skandal keuangan perusahaan misalnya Skandal Perusahaan Toshiba (Mukhlisin, 2015) menunjukkan pentingnya audit, namun prakteknya perusahaan audit mendapatkan kritik tentang pelaksanaan aturan audit yang telah ditetapkan oleh pemerintah Republik Indonesia Nomor 20 Tahun 2015 dan Aturan Etika Standar Profesional Akuntan Publik (SPAP). Pelanggaran praktik audit yang menurunkan citra kualitas audit adalah manipulasi laporan keuangan leh Kantor Akuntan Publik (KAP) Arthur Andersen dan Enron tahun 1995-1997, PT Muzatek Jaya tahun 2004, PT. Kereta Api Indonesia tahun 2005, Gayus Tambunan tahun 2010, dan Bank Mutiara tahun 2012 (Amrizal, 2014). Oleh karena itu, perusahaan audit harus dapat mengembalikan kepercayaan melalui audit yang berkualitas.

Penelitian ini akan mengkaji pandangan dari para pemangku kepentingan (stakeholder) terhadap kualitas audit yang didasarkan pada isu-isu mengenai keahlian dan profesionalisme auditor, komersialisasi audit dan transparansi pelaksanaan audit. Penelitian ini memfokuskan perhatian pada tanggapan dari pelaksanaan peraturan kualitas audit menurut perusahaan audit, komite audit dan investor. Berbeda dengan penelitian terdahulu yang memberikan perhatian pada peraturan kualitas audit sebagai upaya untuk mempengaruhi kualitas audit oleh pihak yang berkepentingan (Hoitash et.al, 2009; Holm dan Mahbub, 2012; Hossain, 2013; Chi et.al, 2013; Kleinman et.al, 2014; Maroun, 2014; Tepalagul dan Ling, 2015). Dalam literatur, kualitas audit dikonseptualisasikan sebagai langkah-langkah output yang biasanya terdiri dari kompetensi dan independensi auditor (Beattie et.al, 2013) meskipun kedua aspek tersebut tidak mewakili seluruh atribut dari kualitas audit. Kualitas menurut DeAngelo dan Palmrose (Maroun, 2014) yang mengemukakan bahwa kualitas audit sebagai probabilitas gabungan untuk mendeteksi dan melaporkan kesalahan laporan keuangan. Para peneliti sering memfokuskan pada hasil yang berhubungan dengan audit. Misalnya hubungan antara keberadaan audit dalam lingkungan tertentu dan perbaikan kredibilitas laporan keungan sering diukur dari kualitas laba (Van Tendeloo dan Vanstraelen 2008), akurasi penilaian auditor dan kebenaran laporan keuangan yang diterbitkan (Knechel dan Vanstraelen, 2007). Kualitas audit tidak dapat diamati oleh mereka yang tidak terlibat dalam proses audit, satu-satunya hasil yang dapat diamati dari proses audit adalah laporan audit (Eilifsen dan Willekens, 2007). Menurut Griffith et.al (2014), penelitian yang dilakukan oleh Hammersley
(2011) dan Hammersley, et.al (2011) menunjukkan bahwa peningkatan jumlah pelaksanaan audit yang terencana diragukan akan meningkatkan kualitas audit. Sedangkan identifikasi masalah khusus oleh auditor akan memungkinkan terkumpulnya bukti yang ditargetkan namun tidak dapat meningkatkan kualitas audit (Hammersley, et.al, 2011 dan Simon, 2012). Selanjutnya, kualitas audit meningkat dengan intervensi yang dirancang langsung untuk auditor dalam berpikir kritis (Hoffman dan Zimbelman, 2009; Simon, 2012). Pelaksanaan prosedur analitis dapat ditingkatkan dengan intervensi auditor (Brewster, 2011).

Pernyataan yang retoris untuk profesi auditor yang berkaitan untuk melayani kepentingan publik bisa menunjukkan adanya ideologi yang berkaitan dengan mempertahankan posisi laporannya (Baker, 2005) dan merupakan bagian integral dari strategi di mana profesi auditor berusaha untuk mengamankan dan meningkatkan material dan nilai simbolis dari kualitas laporan keuangan (Zeff, 2003).

Efektivitas dari profesi audit menyatakan bahwa penyajian kembali laporan keuangan akan menimbulkan pertanyaan "di manakah auditor?". Dalam upaya meningkatkan kualitas audit, maka dibuat rekomendasi yang didalamnya memuat panggilan kepada auditor untuk melakukan beberapa penelusuran tentang prosedur pada setiap audit agar dapat mendeteksi penipuan laporan keuangan. Audit dan kontrol terhadap kualitas standar harus dibuat lebih spesifik dan definitif untuk membantu auditor dalam meningkatkan profesionalitas mereka. Pada aspek tertentu, perusahaan audit harus meninjau secara tepat, meningkatkan metodologi audit, bahan bimbingan dan pelatihan audit. Sebuah sistem peer review untuk "menutup lingkaran" dengan meninjau bahan-bahan laporan dan melaksanakan audit sehingga temuan auditor dapat dilaporkan.

Bermula dari pertemuan yang dilakukan oleh lima orang akuntan dari Indonesia di tahun 1957, maka dibentuklah sebuah perkumpulan akuntan indonesia pertama kali, yang diberi nama Ikatan Akuntansi Indonesia (IAI) pada tanggal 23 Desember 1957 untuk mendorong audit yang mampu berkontribusi terhadap pemulihan kepercayaan pemerintah untuk diaudit. Dalam publikasi tentang kualitas audit, bahwa auditor telah memberikan pelayanan yang berkualitas kepada para pemegang saham jika mereka memberikan laporan audit yang independen, dapat diandalkan dan didukung oleh bukti audit yang memadai. Enam faktor yang berkontribusi terhadap kualitas audi dapat diidentifikasi sebagai berikut, yaitu kepemimpinan yang baik, penilaian 
yang berpengalaman, kompetensi teknis, nilai-nilai etika melalui hubungan klien yang sesuai, praktek-praktek kerja yang tepat dengan kontrol kualitas dan pemantauan proses review yang efektif.

Hal pertama yang diungkapkan dari penelitian ini adalah konsep peraturan dan profesionalisme perusahaan audit untuk menanggapi kekhawatiran atas kualitas audit dengan menggunakan manajemen kesan dimana perusahaan berusaha untuk memulihkan kepercayaan terhadap kualitas audit melalui keterlibatan dalam proses kebijakan tanpa merubah substansi dari pekerjaan audit.

Komitmen untuk melembagakan standar pengaturan dan proses pengawasan yang lebih mandiri telah terbukti dalam memperkuat kualitas audit (Humphrey, et.al., 2007). Peraturan kualitas audit dapat menandai terjadinya pergeseran wacana audit eksternal yang sebelumnya telah memiliki nilai tambah (Knechel, 2007; Peecher, et.al., 2007 dan Power, 2007). Hilangnya kepercayaan publik dalam praktek audit berarti merepresentasikan kecenderungan baru tentang pentingnya audit untuk menciptakan dan mengelola kesan baru untuk memperbaiki citra profesi (Humphrey et al., 2007). Upaya untuk mengembalikan kepercayaan publik dalam proses audit, kepedulian, dan inisiatif dapat diambil oleh badan pengawas yang cenderung untuk memelihara dan mempertahankan atau mengelola domain masing-masing (Cooper dan Robson, 2006; Sikka, 2009)

Manajemen kesan dan legitimasi sangat penting ketika terjadi perdebatan yang berkaitan dengan kualitas audit. Akuntansi badan pengawas dan perusahaan memiliki pencitraan organisasi yang mampu menciptakan dan mempertahankan kesan kegiatan yang sesuai dengan harapan publik (Humphrey et al, 2007). Dalam kewenangan hukum, ketika pertanyaan tentang kualitas audit muncul, maka profesi akuntansi dapat memberikan kesan dan inisiatif untuk mempertahankan dan memperkuat citra ku- alitas audit. Humphrey, et al. (2007) menunjukkan bahwa ketika kualitas audit dalam praktek audit yang ideal maka auditor cenderung menyesuaikan diri dengan model dan retorika untuk menanggapi tekanan institusional.

Untuk melegitimasi keberadaannya, profesi audit memiliki kepentingan dalam meyakinkan pengguna bahwa akuntan dapat dipercaya. Meyakinkan pengguna yang dapat digunakan oleh profesi akuntan adalah manajemen kesan yang secara kelembagaan dapat menghasilkan penampilan simbolis bahwa akuntan rajin melakukan pelayanan publik untuk kepentingan pihak luar luar sehingga kepedulian atas profesi dan anggotanya dapat dilindungi oleh masyarakat (Sikka, 2009).

\section{Metodologi Penelitian}

Sebagai studi pendahulu untuk kerangka kualitas audit, maka dalam penelitian ini memfokuskan kepada Ikatan Akuntansi Indonesia (IAI) sebagai wadah yang mewakili profesi akuntan Indonesia secara keseluruhan dalam membentuk suatu standar akuntansi tersendiri, dan dapat membina akuntan-akuntan Indonesia. Penelitian ini merupakan fokus dari analisis penelitian ini dengan mengidentifikasi empat penggerak utama kualitas audit, yaitu: budaya dalam sebuah perusahaan audit; keterampilan dan kualitas pribadi dari mitra audit dan staf; efektivitas proses audit; keandalan dan kegunaan pelaporan audit. Dalam penelitian ini juga mengidentifikasi sejumlah faktor yang mempengaruhi kualitas audit di luar kendali auditor, yaitu: pendekatan yang diambil oleh manajemen; kontribusi yang dibuat oleh komite audit; peran pemegang saham dan komentator; peran ligitasi sebagai penggerak kualitas audit; pendekatan regulator; tekanan yang disebabkan oleh percepatan laporan. Berikut adalah ringkasan masalah dan respon dari masing-masing kelompok:

Tabel 1 Ringkasan Masalah Berdasarkan Respon Kelompok

\begin{tabular}{lccc}
\hline \multirow{2}{*}{ Variabel } & \multicolumn{3}{c}{ Kelompok } \\
\cline { 2 - 4 } & $\begin{array}{c}\text { Komite } \\
\text { Audit }\end{array}$ & $\begin{array}{c}\text { Perusahaan } \\
\text { Audit }\end{array}$ & Investor \\
\hline Budaya & $56 \%$ & $67 \%$ & $62 \%$ \\
Susunan pegawai & $0 \%$ & $13 \%$ & $14 \%$ \\
Proses & $56 \%$ & $63 \%$ & $48 \%$ \\
Pelaporan & $44 \%$ & $88 \%$ & $67 \%$ \\
Eksternal & $83 \%$ & $81 \%$ & $43 \%$ \\
Kelompok rata-rata & $48 \%$ & $62 \%$ & $47 \%$ \\
\hline
\end{tabular}


Dari tabel di atas, peneliti melihat dari respon yang disampaikan kepada IAI sebagai badan pengaturan standar sebagai bagian dari proses di mana responden terlibat dalam manajemen citra dan retorika. Untuk tujuan penelitian ini, peneliti tidak semata-mata mengandalkan pengkodean kuantitatif tetapi melengkapi pengkodean awal dengan tanggapan terhadap analisis tekstual secara rinci. Peneliti telah berusaha mempertahankan pandangan yang diungkapkan melalui argumen responden untuk mendukung posisi mereka dalam tanggapan secara tertulis. Dengan demikian, peneliti mendasarkan pemeriksaan pada teks yang sebenarnya dari responden yang mencakup kutipan perwakilan. Meskipun tanggapan tertulis memiliki keterbatasan, namun hal tersebut konsisten dengan penelitian sebelumnya.

IAI menerima tanggapan atas kerangka kualitas audit dari usulan perusahaan akuntansi, komite audit, investor, perusahaan dan pemangku kepentingan lainnya. Tanggapan ini berfungsi untuk analisis peneliti. Pendekatan peneliti memfasilitasi perbedaan respon antara kelompok dan memungkinkan pemahaman yang lebih baik dari audit untuk setiap kelompok. Beberapa dari komentar tertulis digunakan untuk menjawab semua pertanyaan yang diajukan, tapi peneliti hanya mempertimbangkan komentar yang memberikan umpan balik. Distribusi responden tersebut terdiri dari: 8 perusahaan audit; 3 komite audit; 7 investor; 1 perusahaan; dan lain-lain. Analisis dalam penelitian ini berfokus pada tiga kelompok pertama (perusahaan audit, komite audit dan investor).

Penelitian ini memberikan analisis terhadap pandangan dari berbagai pihak yang memiliki kepentingan terhadap kualitas audit. Peneliti menitikberatkan pada tanggapan dari pemangku kepentingan dalam kualitas audit untuk mengukur pandangan dan fokus apakah perusahaan audit, komite audit dan investor setuju dengan gagasan-gagasan dari kualitas audit yang dipahami oleh IAI sebagai inisiatif dan pendekatan yang dianggap cukup. Setelah itu, peneliti mengidentifikasi dan mengeksplorasi permasalahan secara mendasar. Peneliti menunjukkan bahwa IAI berfokus pada isu-isu kualitas audit yang tidak secara langsung mengawasi kepentingan perusahaan audit. Peneliti juga menemukan bahwa ada kekhawatiran yang mendasari berpusat pada isu-isu yang terkait dengan keahlian dan profesionalisme auditor, komersialisasi audit, dan transparansi proses audit dari perusahaan audit.

\section{Hasil dan Pembahasan}

Berdasarkan hasil penelitian, peneliti mengidentifikasi empat masalah melalui analisis tanggapan dari penelitian IAI dengan menggunakan kerangka teoritis yang berfokus pada perhatian terhadap peran legitimasi dan manajemen kesan dalam proses regulasi.

Seperti dijelaskan sebelumnya, masalah kualitas audit diklasifikasikan menjadi lima daerah, yaitu budaya perusahaan; susunan pegawai, proses audit, pelaporan audit dan faktor eksternal di luar kendali auditor. Dari ketiga kelompok tidaklah cukup dalam mengatasi kekhawatiran kualitas audit. Apabila dibandingkan dengan badan-komite audit dan kelompok investor, perusahaan audit dianggap relatif tidak cukup. Kelompok investor sebagian besar tidak memadai untuk mengatasi masalah budaya perusahaan audit dan pelaporan audit. Tetapi secara keseluruhan, dianggap memadai terutama dalam kualitas audit yang ditunjukkan dalam budaya perusahaan audit, proses audit dan pelaporan audit.

Chi et al., (2012) mengidentifikasi sejumlah indikator budaya perusahaan yang dapat meningkatkan kualitas audit. Ini termasuk pimpinan perusahaan menekankan pelaksanaan tanggung jawab profesional auditor, menghormati prinsip-prinsip dasar auditing dan etika standar, mitra dan sistem pengembangan pegawai yang dapat meningkatkan karakteristik pribadi yang penting bagi kualitas audit, independensi pertimbangan keuangan dalam proses pengambilan keputusan untuk menghindari efek negatif terhadap kualitas audit, konsultasi masalah yang sulit dan penyediaan sumber daya yang cukup untuk menangani masalah-masalah yang muncul, dan pengembangan infrastruktur informasi untuk mendukung fungsi audit. Hal ini juga mencatat ancaman terhadap budaya yang berorientasi kualitas termasuk kepemimpinan audit yang memiliki cukup masukan untuk keputusan manajemen perusahaan, lebih mengutamakan pemenang untuk mempertahankan audit, lebih mengutamakan pada layanan non-audit, pemotongan biaya yang berlebihan di saat krisis ekonomi, dan menempatkan pentingya pelatihan teknis. Dalam isu yang lebih luas, kelompok responden mengidentifikasi sejumlah faktor yang perlu diperhatikan lebih lanjut. Berikut ini peneliti meringkas dan kemudian membahas penilaian responden yang dihubungkan dengan isu-isu spesifik yang mempengaruhi kualitas audit: 
Tabel 2 Masalah Kualitas Audit

(\% Mempertimbangkan Ketidakcukupan)

\begin{tabular}{|c|c|c|c|}
\hline & $\begin{array}{c}\text { Komite } \\
\text { Audit }\end{array}$ & $\begin{array}{c}\text { Perusahaan } \\
\text { Audit }\end{array}$ & Investor \\
\hline \multicolumn{4}{|l|}{ Budaya dalam perusahaan } \\
\hline Identifikasi dari faktor-faktor penting budaya sebuah perusahaan audit & $33 \%$ & $50 \%$ & $14 \%$ \\
\hline Identifikasi tekanan yang dapat membahayakan budaya perusahaan audit & $67 \%$ & $88 \%$ & $86 \%$ \\
\hline Langkah lebih lanjut untuk membangun kepercayaan budaya perusahaan audit & $67 \%$ & $63 \%$ & $86 \%$ \\
\hline \multicolumn{4}{|l|}{ Susunan pegawai } \\
\hline Keterampilan teknis, kualitas pribadi dan pengalaman sebagai pendorong utama & $0 \%$ & $0 \%$ & $0 \%$ \\
\hline Identifikasi isu terhadap kecukupan pegawai terlatih/tenaga kerja terampil & $0 \%$ & $25 \%$ & $29 \%$ \\
\hline \multicolumn{4}{|l|}{ Proses Audit } \\
\hline Identifikasi seluruh faktor yang menentukan efektivitas proses audit & $0 \%$ & $63 \%$ & $43 \%$ \\
\hline Identifikasi semua ancaman terhadap efektivitas proses audit & $100 \%$ & $63 \%$ & $43 \%$ \\
\hline Langkah untuk melawan ancaman terhadap efektivitas proses audit & $67 \%$ & $63 \%$ & $57 \%$ \\
\hline \multicolumn{4}{|l|}{ Pelaporan Audit } \\
\hline Identifikasi faktor-faktor yang mempengaruhi kepercayaan opini audit & $67 \%$ & $88 \%$ & $71 \%$ \\
\hline Alasan lain pengguna tidak memiliki keyakinan dalam opini audit & $67 \%$ & $100 \%$ & $57 \%$ \\
\hline Langkah lebih lanjut untuk memperkuat kepercayaan opini audit & $0 \%$ & $75 \%$ & $71 \%$ \\
\hline \multicolumn{4}{|l|}{ Masalah Lain } \\
\hline Identifikasi faktor eksternal negatif yang dapat mempengaruhi kualitas audit & $100 \%$ & $88 \%$ & $29 \%$ \\
\hline Langkah untuk mengurangi risiko faktor eksternal dalam proses audit & $67 \%$ & $75 \%$ & $57 \%$ \\
\hline
\end{tabular}

Secara keseluruhan responden mengenal budaya sebagai isu penting dari kualitas audit (Chi et al., 2012). Kebanyakan investor dan badan-komite audit menemukan faktor isu budaya pada kualitas audit hasil dari diidentifikasi menjadi laporan yang cukup. Namun perusahaan audit mengidentifikasi bahwa faktor-faktor lain juga sama pentingnya. Faktor tambahan yang dikemukakan oleh perusahaan audit meliputi: tingkat keterlibatan mitra dalam audit, tingkat kekompakan perusahaan/jaringan internasional, pentingnya audit perusahaan, struktur kepemilikan dan manajemen perusahaan, kesediaan perusahaan untuk berkontribusi secara luas (komitmen untuk kepentingan umum), dan pengalaman perusahaan dalam audit sesuai dengan kepentingan publik.

Faktor penggerak lain dari kualitas audit menurut Chi et al., (2012) berkaitan dengan keterampilan dan kualitas pribadi pegawai dari mitra audit. Hal tersebut dapat diartikan bahwa pelatihan yang diberikan kepada pegawai audit harus dikoordinasikan agar sesuai dengan pekerjaan audit yang mereka lakukan. Dalam kegiatan pelatihan, manajer dan mitra perlu melakukan mentoring kepada pegawai untuk mengatasi bebagai permasalahan audit agar setelah mengikuti pelatihan pegawai lebih fokus untuk mengatasi permasalahan audit secara tepat. Selain itu, Chi et al., (2012) juga mengidentifikasi beberapa ancaman terhadap keterampilan tim audit yang meliputi: kegagalan pengembangan karakteristik pribadi untuk melakukan pendampingan yang efektif, kegagalan mempertahankan pegawai yang memiliki pengalaman dan keahlian yang diperlukan, mengalokasikan pegawai yang memilih prestise klien daripada risiko audit; dan pelatihan yang tidak efektif.

Dalam meningkatkan kualitas audit, Peneliti mengidentifikasi karakteristik sebagai berikut: dapat diandalkan, laporan keuangan yang berguna, keyakinan dan komunikasi yang baik dengan komite audit. Bentuk laporan auditor dikodifikasi dan standar (Manson \& Zaman, 2001). Elemen utama yang ditentukan dalam standar hukum audit adalah laporan auditor yang bersih dapat dijadikan sumber informasi baru dan laporan auditor terkait dengan kepercayaan dalam proses audit. Komunikasi yang baik dengan komite audit dapat memberikan kontribusi terhadap kualitas hasil audit (Zaman et al, 2011). Manfaat komunikasi dengan komite audit meliputi: adanya dialog tentang ruang lingkup audit, membuktikan adanya forum yang mendiskusikan identifikasi dari risiko utama dan membuat penilaian untuk meraih opini audit, membahas aspek kualitatif dari akuntansi entitas, pelaporan dan cara-cara potensial untuk meningkatkan pelaporan keuangan. 
Dalam hal kecukupan kualitas audit, , tidak ada satupun responden yang dianggap sebagai unsur opini audit. Perusahaan audit menemukan lebih banyak alasan atas kecukupan karena pengguna tidak memiliki keyakinan dalam opini audit dibandingkan dengan investor sebanyak 57\%. Keyakinan investor merupakan suatu kewajaran karena investor memiliki wawasan lebih tentang proses audit (Carcello et.al, 1992). Hal tersebut tercermin dari keseluruhan tingkat penilaian wilayah cakupan yang dibandingkan dengan ketidakcukupan dari kelompok responden. Perusahaan audit kurang puas terhadap faktor dan ancaman yang diidentifikasi dibandingkan dengan investor. Sebaliknya, komite audit menemukan bahwa masalah proses audit cukup tertutup.

Tanggapan dari berbagai kelompok menimbulkan pertanyaan tentang kelayakan kerangka kualitas audit. Kerangka kualitas audit tidak secara langsung dapat mengatasi masalah secara fundamental atas kritik mengenai kualitas audit. Penggunaan manajemen kesan dan legitimasi sebagai kerangka kerja untuk menganalisis tanggapan pemangku kepentingan memungkinkan dapat melampaui faktor yang diidentifikasi oleh peneliti yang tidak secara langsung mengancam kepentingan komersial perusahaan audit. Fokus permasalahan yang mendasari, berpusat pada isu-isu yang berkaitan dengan keahlian dan profesionalisme auditor, komersialisasi audit, dan transparansi proses audit serta perusahaan audit.

Isu utama yang berkaitan dengan keahlian individu yang terlibat dalam proses audit adalah kekhawatiran tentang kualitas audit. inti dari semua profesi terletak pada keahlian anggotanya, Profesi audit dikarakteristikan dengan daya tariknya terhadap himpunan pengetahuan yang unik (Bedard, 1989). Pernyataan tersebut tidak sesuai apabila terjadi kegagalan yang tidak terduga, penipuan dan kegagalan yang menimbulkan anggapan bahwa auditor tidak memiliki keahlian (Sikka, 2009). Keahlian auditor ditekankan dalam rangka kualitas audit, namun tidak membahas kurangnya keahlian mengakibatkan kegagalan seperti diperlihatkan pada krisis perbankan (Sikka, 2009).

Analisis dari tanggapan responden menunjukkan semua kelompok responden setuju dengan keterampilan teknis, kualitas pribadi dan pengalaman praktis dari anggota audit yang merupakan pendorong utama dari kualitas audit. Responden juga berpikir bahwa permasalahan yang berpengaruh terhadap pegawai yang kurang terlatih atau terampil. Sementara itu, beberapa responden memberikan tambahan komentar tentang masalah kepegawaian yang di- sebabkan oleh kekhawatiran mengenai kompetensi pegawai. Responden mengidentifikasi kompetensi pegawai audit dan pentingnya perekrutan pegawai yang berkualitas. Seorang responden dari investor mengamati bahwa: masalah yang tidak ditangani langsung adalah kenyataan dari sebagian besar klien menganggap bahwa tanggungjawab pekerjaan audit dilakukan oleh pegawai yang memiliki pengalaman tiga tahun.

Ancaman yang dikemukakan oleh komite audit termasuk keterlibatan tim yaitu peningkatan kompleksitas dapat menyebabkan tuntutan terhadap kualitas keterampilan auditor yang kurang memahami kebutuhan pengguna. Mereka juga memperingatkan kepala eksekutif atau klien yang mendominasi memiliki potensi resiko sehingga beberapa perusahaan audit khawatir tentang profesionalisme pegawai. Faktor yang dapat menimbulkan dampak negatif terhadap kualitas audit adalah personil perusahaan memberikan informasi yang tidak akurat, dalam membuat dokumen atau informasi tidak tepat waktu, dan berusaha mengatur pesan ke direksi perusahaan. Selain itu, Mereka juga mengamati bahwa ancaman terhadap kualitas audit muncul ketika komite audit tidak memiliki kepemimpinan.

\section{Profesionalisme}

Selain proses audit, kualitas audit dipengaruhi oleh profesionalisme auditor dan pembuat laporan keuangan karena profesionalisme atau tenaga ahli auditor merupakan dimensi penting dari kualitas audit. Namun, perusahaan audit juga memiliki keuntungan dengan membuat kelompok auditor sehingga keberhasilan perusahaan dapat diukur dengan adanya peningkatan biaya dan keuntungan. Hal yang berpotensi merusak profesionalisme auditor perusahaan dan kualitas audit adalah penyedia jasa konsultasi yang meyebabkan perbedaan. Faktor pendorong yang keempat dalam kualitas audit adalah budaya perusahaan audit yang terdiri dari keterampilan dan kualitas probadi dari mitra audit serta pegawai audit, efektivitas proses audit; dan keandalan atau kegunaan pelaporan audit. Kualitas audit tidak memberikan bobot yang disebabkan oleh ancaman terhadap profesionalisme auditor. Sebuah risiko dalam mengaudit profesionalisme adalah kenyataan bahwa karyawan perusahaan audit memprioritaskan kepentingan klien audit dan pengetahuan karyawan tentang kemajuan karir mereka (Grey, 1998)

Menanggapi hal tersebut, perusahaan audit mencatat faktor tambahan dalam mengidentifikasi dari isu yang tidak menimbulkan risiko lansung terhadap kepentingan komersial dari perusahaan audit. 
Kepedulian yang dinyatakan oleh perusahaan audit adalah pengaruh peningkatan kebijakan dari laporan keuangan yang diaudit, kebijakan yang berlebihan, dan dokumentasi audit melalui pendekatan aturan. Perusahaan audit menekankan perlunya kebijakan dengan prinsip "standar pemikiran auditor" yang didukung oleh pandangan dari komite audit. Identifikasi terhadap risiko besar adalah ketergantungan pada standar dan kebijakan yang mempertimbangkan ketepatan pendekatan untuk setiap individu. Sementara itu, komite audit memperingatkan ancaman di banyak perusahaan audit yang merubah aturan tentang keterlibatan mitra.

\section{Komersialisasi}

Masalah dasar mempengaruhi kualitas audit adalah komersialisasi audit. sementara itu, empat pendorong utama dari kualitas audit yaitu budaya perusahaan audit; keterampilan dan kualitas pribadi dari mitra serta karyawan audit, efektivitas proses audit; keandalan dan kegunaan laporan audit. Peneliti menemukan bahwa komersialisasi merupakan faktor pentingan penting yang mempengaruhi kualitas audit. Badan-komite audit mengetahui motif keuntungan dari perusahaan audit yang dapat melemahkan kualitas audit dan memiliki kontribusi terhadap kegagalan.

Dari hasil tanggapan responden (perusahaan audit, komite audit dan investor), peneliti menemukan faktor lain dari faktor pendorong kualitas audit yang diidentifikasi, yaitu biaya audit yang terlalu rendah dan kemampuan untuk mempertahankan karyawan yang berkualitas. Responden juga berpendapat bahwa bahwa kebijakan yang berlebihan akan membentuk budaya perusahaan audit. Komite audit menekankan bahwa kepatuhan terhadap aturan akan mengorbankan aspek penting dari kualitas audit. Salah satu perusahaan audit menyatakan bahwa: Interaksi antara persyaratan audit dan biaya yang meningkat berpotensi untuk menghambar kualitas pekerjaan audit

Sementara itu, kelompok investor mengidentifikasi tekanan terhadap kualitas audit, yaitu kepemimpinan yang lemah, pelatihan, komunikasi, moralitas karyawan yang tidak baik, tanggung jawab dan akuntabilitas yaang kurang jelas. Lebih lanjut, kelompok investor menidentifikasi tekanan yang memfokuskan pada layanan non-audit dan tujuan komersial perusahaan untuk memaksimalkan pendapatan. Hal tersebut sesuai dengan pernyataan investor: Kompromi rahasia antara perusahaan audit dan klien berfungsi sebagai budaya perusahaan.
Komite audit dan perusahaan audit tidak setuju dengan faktor tambahan yang dikemukakan oleh komite audit meliputi: kebutuhan pandangan yang lebih luas dari kualitas audit bukan hanya berfokus pada "kualitas pasar", standar kualitas yang dihasilkan dari informasi klien, mengumumkan keuntungan yang telalu cepat, dan meningkatnya kompleksitas standar pelaporan keuangan. Selanjutnya, komite audit menunjukkan bahwa secara luas proses audit sebagai bagian dari tata kelola perusahaan dan kerangka pelaporan keuangan. Komite audit menekankan bahwa : Stakeholder secara berkala meninjau kembali praktek profesional yang sesuai dengan harapan

Faktor lain yang perlu dipertimbangkan lebih lanjut oleh perusahaan audit adalah persiapan dan kewajiban untuk menyelesaikan masalah terdahulu, nilai lebih dari laporan keuangan, meningkatnya globalisasi, pusat layanan bersama jarak jauh yang menggunakan IT. Salah satu perusahaan audit memperingatkan bahwa: Standar komunikasi jarak jauh akan mempengaruhi kualitas audit.

\section{Transparansi}

Dari empat faktor pendorong dari kualitas audit yaitu budaya perusahaan audit, keterampilan dan kualitas probadi dari mitra audit dan karyawan, efektifitas proses audit, keandalan dan kegunaan laporan audit, sehingga tidak mengakui adanya transparansi dari proses audit pada perusahaan audit, terutama kode tata kelola perusahaan yang bertujuan untuk meningkatkan transparansi perusahaan meskipun sedikit perusahaan audit yang membuat proses audit atau tata kelola yang transparan. Perusahaan audit tidak mematuhi ketentuan yang berlaku tentang transparansi untuk perusahaan yang sama atau badan sektor publik. Perbedaan antara kepentingan investor dan perusahaan audit terlihat jelas ketika membandingkan kualitas audit. Investor memfokuskan pada transparansi untuk profesi auditor sedangkan perusahaan audit mendukung langkah untuk meningkatkan kesadaran terhadap masalah budaya yang terjadi antara pemangku kepentingan serta menciptakan pemahaman mengenai baik dan buruk di dalam praktek audit. Selanjutnya, investor meminta informasi yang lebih detail mengenai budaya dan kebijakan dari perusahaan audit, misalnya salah satu investor memperlihatkan informasi tentang ketentuan tugas audit.

Para investor menyatakan kekhawatiran tentang kemampuan perusahaan audit untuk menerapkan dan mengadaptasi proses audit di dalam perubahan lingkungan bisnis. Mengingat banyaknya kon- 
sentrasi audit, maka diperlukan harmonisasi standar antara audit internasional dengan standar audit nasional. Investor menginginkan langkah spesifik yang dapat dipertanggungjawabkan dalam memberikan informasi yang relevan. Hal tersebut sesuai dengan pernyataan responden dari investor yang mengatakan bahwa: Meyakinkan kembali perhatian yang diberikan memiliki kesamaan dalam jaringan standar perusahaan.

Komite audit dan perusahaan audit keduanya berpendapat bahwa faktor tambahan yang mendapat perhatian adalah reputasi perusahaan audit dan mitra. Beberapa perusahaan audit menyatakan ketidakpeduliannya terhadap opini audit, yaitu: Kami tidak mempercayai bahwa kepercayaan diri dalam opini audit dipengaruhi secara signifikan oleh bentuk laporan atau kata-kata. Kuncinya adalah kualitas dan reputasi perusahaan audit menyediakan pendapat yang didukung oleh reputasi keseluruhan profesi audit.

Perusahaan audit menunjukkan bahwa kepercayaan bisa ditemukan dalam sebuah pendapat dan tidak berbentuk kata. Mereka berpendapat bahwa opini audit seharusnya sederhana dan panjangnya kata yang legalistik tidak membantu pemahaman. Kekhawatiran ini juga dimiliki oleh investor: Persyaratan opini audit harus berhubungan dengan keputusan mengenai kebenaran, bukan ditujukan untuk siapa dan untuk apa audit dilakukan.

Sebuah perusahaan audit memiliki kesulitan dalam melihat komunikasi auditor sebagai bagian dari kualitas audit dan menunjukkan bahwa: Sebagian besar perhatian tertuju pada laporan keuangan dibandingkan kualitas audit.

Hal tersebut menunjukkan perbedaan pendapat yang dikemukakan oleh investor. Faktor yang dikemukakan oleh investor adalah keduanya menginginkan bentuk laporan audit yang lebih informatif. Tanda tangan yang diberikan oleh auditor dapat memberikan sinyal positif. Mereka juga mengatakan bahwa "penekanan masalah materi" berpotensi meningkatkan kualitas audit. Salah satu investor berpikir mengenai informasi lebih lanjut dapat memberikan pemahaman cara pembentukan opini. Khususnya opini audit tentang konsolidasi laporan keuangan dan informasi tentang gambaran kelompok yang tidak diaudit. Salah satu investor menunjukkan bahwa: Opini audit yang lebih diskursif harus mendorong pemegang saham dan investor untuk menginterpretasikan opini audit.

Perusahaan audit juga melihat peran komite audit dalam menghentikan kesenjangan harapan anta- ra auditor dan pengguna. Salah satu perusahaan menunjukkan peningkatan keterbukaan informasi langsung antara komite audit dan pemegang saham atau menyediakan komunikasi yang formal antara komite auditor dan audit.

\section{Kesimpulan}

Kecurangan yang terjadi di dalam perusahaan menjadi penyebab perdebatan tentang kualitas audit. Bersamaan dengan berbagai upaya yang diterapkan bertujuan untuk memulihkan kepercayaan dalam audit dan pemerintahan, upaya yang dilakukan oleh IAI adalah mengembangkan 'Kerangka Audit Mutu yang ditandai dengan perkembangan akuntan di Indonesia. Tidak ada badan pengawas lainnya yang mencoba atau perlu menyusun kualitas audit. Dalam konteks penelitian akademis terhadap kualitas audit, penelitian ini difokuskan pada respon dari tiga kelompok, yaitu badan akuntansi profesional, perusahaan audit dan investor. Peneliti menemukan bahwa kelompok responden memberikan tanggapan tentang perlunya IAI mengatasi masalah tambahan dalam meningkatkan kualitas audit. Untuk melegitimasi keberadaannya, profesi audit memiliki kepentingan meyakinkan pengguna bahwa akuntan dapat dipercaya. Sementara pendapat investor bahwa usulan tentang kualitas audit menunjukkan masalah yang disebabkan oleh perusahaan audit dan komite audit yang melindungi kepentingan badan akuntansi profesional perusahaan dan anggota individu. Dilihat dari posisi perusahaan audit, mementingkan cara pencegahan dan pentingnya pengakuan peran penilaian profesional di bidang kualitas audit. Secara umum, banyak yang mendukung usulan bahwa perusahaan audit menginginkan peran pihak lain (khususnya komite audit) untuk meningkatkan kualitas audit.

Fokus dari analisis penelitian ini melampaui permasalahan yang diidentifikasi secara tidak langsung mengancam kepentingan komersial perusahaan audit. Selain itu, fokus penelitian didasarkan pada kekhawatiran terhadap isu yang terkait dengan keahlian dan profesionalisme auditor, komersialisasi audit, dan kebijakan transparansi proses audit dari perusahaan audit yang belum mendapat banyak perhatian. Perhatian perusahaan audit dalam memfokuskan audit pada masalah teknis sehingga empat masalah kualitas audit yang belum terselesaikan. Analisis peneliti menunjukkan bahwa kualitas audit tidak hanya fenomena teknis, namun sebagai bagian dari retorika yang digunakan oleh pemegang kebijakan, komite audit dan perusahaan audit sehingga mengakibatkan kurangnya kepercayaan terhadap audit setelah perusahaan mengalami ke- 
gagalan. Berbeda dengan faktor pendorong kualitas audit yang telah diidentifikasi, bahwa fokus peneliti adalah transparansi, keahlian, profesionalisme dan komersialisasi yang menunjukkan bahwa perusahaan audit dan komite audit memfokuskan pada masalah yang menimbulkan ancaman bagi kepentingan komersial perusahaan audit. Menariknya, gagasan kualitas audit yang diidentifikasi tidak didasarkan pada analisis sistematis kegagalan audit. Upaya untuk mengembalikan kepercayaan dan legitimasi peraturan suatu badan seperti IAI adalah melakukan rekonsiliasi pertentangan tuntutan di antara pemangku kepentingan. Secara keseluruhan, analisis peneliti menunjukkan bahwa badan pengawas dan profesional terlibat dalam manajemen dan peningkatan kualitas audit melakukan upaya untuk memperbaiki citra yang tercoreng, meningkatkan legitimasi dan reputasi serta dominasi tanggapan yang menimbulkan kekhawatiran terhadap potensi kerusakan pada profesi.
Keterbatasan dalam penelitian ini adalah respon terhadap laporan yang tidak mencakup tentang pemeriksaan/penelusuran terkait dengan perubahan regulator, posisi komite audit atau perusahaan audit dalam jangka waktu kualitas audit. Peneliti selanjutnya dapat memperluas dan memberikan pemahaman tentang masalah yang ditelit. Selain itu, kepercayaan terhadap respon tidak memberikan bukti kualitas dalam praktek audit. Penelitian lebih lanjut diperlukan untuk mengetahui pengaruh inisiatif keputusan dari luar yang diserap dalam praktek perusahaan audit. Demikian penelitian mengenai kualitas audit dapat mengkaji efek terhadap perilaku aktual audit, pengaturan kelembagaan dan peraturan yang dapat memberikan kontribusi pada literatur kualitas audit. Dalam melakukan penelitian empiris tersebut, peneliti sebaiknya memeriksa kondisi yang mempengaruhi pernyataan peraturan tentang kualitas audit dan kinerja aktual audit

\section{REFERENSI}

Amrizal. (2014). Analisis Kritis Pelanggaran Kode Etik Profesi Akuntan Publik Di Indonesia. Jurnal Liquidity. Vol. 3 No. 1. H. 36-43

Beattie, Vivien, Stella Fearnley dan Tony Hines (2013) Perceptions of factors affecting audit quality in the post-SOX UK regulatory environment. Accounting and Business Research. Vol. 43. No. 1. H. 56-81, DOI: 10.1080/00014788.2012.703079

Brewster, B. E. (2011). How a Systems Perspective Improves Knowledge Acquisition and Performance in Analytical Procedures. The Accounting Review. Vol. 86. H. 915-43.

Chi, Wuchun, Linda Hughen, Chan-Jane Lin and Ling Lei Lisic. (2012) Determinants of Audit Staff Turnover: Evidence from Taiwan. International Journal of Auditing. Vol. 17, No. 1, H.100-112, 2013. doi:10.1111/ j.1099-1123.2012.00459.x

Cooper, D. J., dan Robson, K. (2006). Accounting, professions and regulation: Locating the sites of professionalization. Accounting, Organizations and Society. Vol. 31. No. 4-5. h. 415-444.

Eilifsen, A., dan Willekens, M. (2007). In the name of trust. In R. Quick, S. Turley, \& M. Willekens (Eds.), Auditing trust and governance. London: Routledge

Griffith, Emily E. (2014). Auditor Mindsets and Audits of Complex Estimates. Journal of Accounting Research. Vol. 53. No. 1. H. 49-77. DOI: 10.1111/1475-679X.12066

Hammersley, J. S. (2011). A Review and Model of Auditor Judgments in Fraud-Related Planning Tasks. Auditing: A Journal of Practice \& Theory. Vol. 30. H. 101-28.

Hammersley, J. S.; K. M. Johnstone; dan K. Kadous (2011). How Do Audit Seniors Respond to Heightened Fraud Risk?. Auditing: A Journal of Practice \& Theory. Vol. 30. h. 81-101.

Hoffman, V. B., dan M. F. Zimbelman. (2009). Do Strategic Reasoning and Brainstorming Help Auditors Change Their Standard Audit Procedures in Response to Fraud Risk?. The Accounting Review. Vol. 84. H. 811-37

Holm, Claus dan Mahbub Zaman. (2012). Regulating audit quality: Restoring trust and legitimacy. Accounting Forum. Vol. 36. H. 51-61. DOI:10.1016/j.accfor.2011.11.004 
Humphrey, C., Khalifa, R., Robson, K., dan Sharma, N. (2007). Making quality auditable: An analysis of the contemporary audit regulatory arena. In Paper presented at the national auditing conference Dublin, 24-25th March 200

Hoitash, Udi, Rani Hoitash, dan Jean C. Bedard. (2009). Corporate Governance and Internal Control over Financial Reporting: A Comparison of Regulatory Regimes. The Accounting Review. Vol. 84 No. 3. h. 839-867.

Hossain, Sarowar. (2013). Effect of Regulatory Changes on Auditor Independence and Audit Quality. International Journal of Auditing. Vol. 17 No. 3. h. 246-264

Kleinman, Gary, Beixin Betsy Lin dan Dan Palmon. (2014). A Cross-National Comparison of Audit Regulatory Regimes. Journal of Accounting, Auditing \& Finance. Vol. 29 No. 1. h. 61-87. doi: 10.1177/0148558X13516127

Knechel, W., dan Vanstraelen, A. (2007). The relationship between auditor tenure and audit quality implied by going concern opinions. Auditing: A Journal of Practice and Theory. Vol. 26. No. 1. H. 113-131

Knechel, W. R. (2007). The business risk audit: Origins, obstacles and opportunities. Accounting, Organizations and Society. Vol 32. No. 4-5. H. 383-408.

Maroun, Warren. (2014). Reportable irregularities and audit quality: Insights from South Africa. Accounting Forum. Vol 39. No. 1. H. 19-33. di:10.1016/j.accfor.2014.03.002

Mukhlisin, Murniati. (23 Juli 2015) Skandal Akuntansi Toshiba dan Tantangan Bisnis Lembaga Syariah. website: http://www.republika.co.id/berita/jurnalisme-warga/wacana/15/07/23/nrx7kl-skandal-akuntansi-toshiba-dan-tantangan-bisnis-lembaga-syariah-1

Peecher, M. E., Schwartz, R., dan Solomon, I. (2007). It's all about audit quality: Perspectives on strategic systems auditing. Accounting, Organizations and Society. Vol. 32. No. 463-485

Power, M. (2007). Business risk auditing - Debating the history of its present. Accounting, Organizations and Society. Vol. 32. No. 4-5. H. 379-382.

Sikka, P. (2009). Financial crisis and the silence of the auditors. Accounting Organizations and Society. Vol. 34. No. 6/7. H. 868-873

Simon, C. A.. (2012). Individual Auditors' Identification of Relevant Fraud Schemes. Auditing: A Journal of Practice \& Theory. Vol. 31. H. 1-16.

Turley, S., dan Zaman, M. (2007). Audit committee effectiveness: A case study of informal processes and behavioural effects. Accounting, Auditing \& Accountability Journal. Vol. 20 No. 5. H. 765-788

Van Tendeloo, B., dan Vanstraelen, A. (2008). Earnings management and audit quality in Europe: Evidence from the private client segment market. European Accounting Review. Vol. 3. H. 447-469

Wuchun Chi, Ling Lei Lisic, Xiaohai Long, dan Kun Wang. (2013). Do regulations limiting management influence over auditors improve audit quality? Evidence from China. Journal of Accounting and Public Policy. Vol. 32 No. 2. h. 176-187.

Zaman, M., Hudaib, M., dan Haniffa, R. (2011). Corporate governance quality, audit fees and non-audit fees. Journal of Business Finance \& Accounting. Vol. 38. No. 1-2. H. 165-197. 